\title{
Use of Sepiolite and Zeolite Mixtures as a Landfill Liner
}

\author{
Ahmet Tuncan*, Mehmet Inanc Onur, Kazım Akpinar and Mustafa Tuncan \\ Department of Civil Engineering, Anadolu University, Eskisehir, Turkey
}

\begin{abstract}
This study presents an investigation into the possibility of using sepiolite and zeolite mixtures to design a landfill liner. Leakage from the impervious layer into the environment is the main difficulty of storing hazardous waste. Therefore, determining the impermeable layer and in-situ application procedure is very important and needs laboratory experimentation. For this purpose, a series of experiments have been conducted on a mixture of zeolite+sepiolite. The geotechnical, physico-chemical and micro-structural properties of $30 \%$ sepiolite by weight of zeolite have been determined through laboratory testing. At the end of the research, the results show that zeolitesepiolite mixtures can be effectively used in bottom lining systems for hazardous, industrial and municipal waste.
\end{abstract}

Keywords: Sepiolite; Zeolite; Landfill liner; Geotechnical and chemical properties

\section{Introduction}

Waste disposal sites are areas of soil and groundwater contamination in industrialized countries. Leachate generated from water percolating through waste is a principal carrier of soluble and suspended contaminants in an impermeable liner. Proper management of leachate is important to minimize the risk of contamination of soil and groundwater. Properly designed lining and capping systems are essential for the protection of the surrounding environment. The construction of correct lining systems also has importance in reducing the risk to the environment through design procedure.

Güney et al. [1] investigated the feasibility of using kaolinite, sepiolite, zeolite and their mixtures as a bottom liner material. They indicate that sepiolite is the dominant material that affects both geo mechanical and geo environmental properties of these alternative liners. They conclude that an increase in the sepiolite content in sepiolite + zeolite mixtures increases the strength, swelling potential and metal adsorption capacity of the soil mixtures. Sun et al. [2] considered microbial properties, such as microbial community and enzyme activities, chemical properties, such as $\mathrm{p}^{\mathrm{H}}$ and metal fraction and heavy metal accumulation in spinach to assess stabilization remediation effectiveness using sepiolite. Their results show that soil $\mathrm{p}^{\mathrm{H}}$ increases with rising sepiolite concentration. An addition of sepiolite converted significant amounts of the exchangeable fraction of $\mathrm{Cd}$ and $\mathrm{Pb}$ into residual form. Benson et al. [3] investigated the hydraulic conductivity (permeability) of compacted clay liners. Hydraulic conductivity measurements were conducted on a wide variety of soils from 67 landfills in North America. They found that the hydraulic conductivity values were less than $1 \times 10^{-7} \mathrm{~cm} / \mathrm{sec}$.

Simon and Muller [4] refer to standards for alternative cover lining materials and design criteria in Germany. Jain et al. [5] investigated heavy metal concentrations of old and new sanitary landfill liner systems. Tuncan et al. [6] studied using natural zeolite as a landfill liner. Different ratios of bentonite and zeolite mixtures were compacted with an optimum water content. Shear strength parameters, permeability, $\mathrm{p}^{\mathrm{H}}$ heavy metal content and other properties of compacted mixtures were determined. They conclude that $\mathrm{B} / \mathrm{Z}=0.10$ ratio is the ideal mixture for sanitary land fill liner material. Ozdemir [7] studied using sepiolite as a sanitary liner. He concludes that sepiolite could be used with kaolinite as a landfill material.

Typically, hydraulic conductivity must be less than or equal to $1 \times 10$ ${ }^{7} \mathrm{~cm} / \mathrm{sec}$ for soil liners and covers used to contain hazardous waste, industrial waste and municipal waste [8]. One important aspect of hydraulic barriers is the cation exchange capacity (CEC) of the liner material. The most common clay minerals, such as kaolinite, illite and chlorite have CEC values of between 5 and $40 \mathrm{meq} / 100 \mathrm{~g}$ [9], whereas natural zeolites have CEC values of between 200 and 400 [10].

A miniature artificial landfill tank $(3 \mathrm{~m} \times 1 \mathrm{~m} \times 0.50 \mathrm{~m})$ was constructed in order to simulate an actual in-situ application $30 \%$ sepiolite mixed zeolite was compacted and layered in the tank. The tank was divided into six sections. Each section was $0.50 \mathrm{~m} \mathrm{x} 0.50 \mathrm{~m} \mathrm{x} 0.50$ $\mathrm{m}$ in dimension. After 28 days curing time, copper and chromium were poured into each pair of parts, separately and distilled water was also poured into two parts for comparison. The tank was observed for sixteen weeks. Nylon covered on the tank to prevent evaporation. Leachate samples were collected from the bottom of the tank to determine physico-chemical properties of the leachate. Changes in geotechnical and physico-chemical properties of the sepiolite mixed zeolite, before and after the experiment, were determined. Scanning electron microscope pictures were also taken to observe the microstructure of both contaminated and uncontaminated samples.

\section{Materials}

\section{Sepiolite}

In this study, sepiolite was obtained from the city of Eskisehir, Turkey. The chemical composition of sepiolite consists of $55.97 \%$, $\mathrm{SiO}_{2}, 22.81 \% \mathrm{MgO}, 1.56 \% \mathrm{Al}_{2} \mathrm{O}_{3}, 0.12 \% \mathrm{Na}_{2} \mathrm{O}, 0.27 \% \mathrm{~K}_{2} \mathrm{O}, 0.77 \%$ $\mathrm{Fe}_{2} \mathrm{O}_{3}, 0.02 \% \mathrm{MnO}, 0.125 \mathrm{TiO}_{2}, 0.57 \% \mathrm{CaO}, 17.75 \%$ Loss of Ignition [6]. Sepiolite is a magnesium hydro silicate clay mineral. It has a fiber structure form. Certain physico-chemical and geotechnical properties are shown in Table 1.

*Corresponding author: Tuncan A, Department of Civil Engineering, Anadolu University, Eskisehir, Turkey. Tel: + 90.222.321.3550; Fax: + 90222.323950; E-mail: atuncan@anadolu.edu.tr

Received January 02, 2016; Accepted January 19, 2016; Published January 26 2016

Citation: Tuncan A, Onur MI, Akpinar K, Tuncan M (2016) Use of Sepiolite and Zeolite Mixtures as a Landfill Liner. Int J Waste Resour 6: 197. doi: 10.4172/2252 5211.1000197

Copyright: $\odot 2016$ Tuncan A, et al. This is an open-access article distributed under the terms of the Creative Commons Attribution License, which permits unrestricted use, distribution, and reproduction in any medium, provided the original author and source are credited. 
Citation: Tuncan A, Onur MI, Akpinar K, Tuncan M (2016) Use of Sepiolite and Zeolite Mixtures as a Landfill Liner. Int J Waste Resour 6: 197. doi: 10.4172/22525211.1000197

\begin{tabular}{|c|c|c|}
\hline Properties & Zeolite* $^{*}$ & Sepiolite $^{\#}$ \\
\hline $\mathrm{pH}$ & 9.50 & 7.72 \\
\hline $\begin{array}{c}\text { Electrical conductivity } \\
(\mathrm{mS} / \mathrm{cm})\end{array}$ & 2.69 & 0.3 \\
\hline $\begin{array}{c}\text { Cation exchange capacity } \\
\text { (meq/100g) }\end{array}$ & 90 & $20-30$ \\
\hline Specific Gravity & 2.60 & 2.50 \\
\hline Silt (\%) & 12 & 31 \\
\hline Clay (\%) & 88 & 132 \\
\hline Liquid Limit (\%) & 60 & 85 \\
\hline Plastic Limit (\%) & 32 & 39 \\
\hline Shrinkage Limit (\%) & \# Taken from [6] & \\
\hline
\end{tabular}

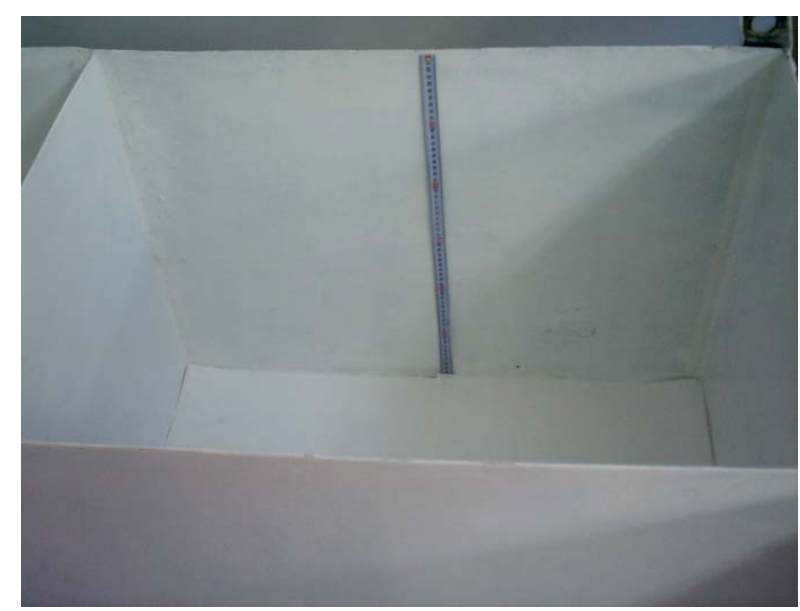

Figure 1: Landfill tank with a division.

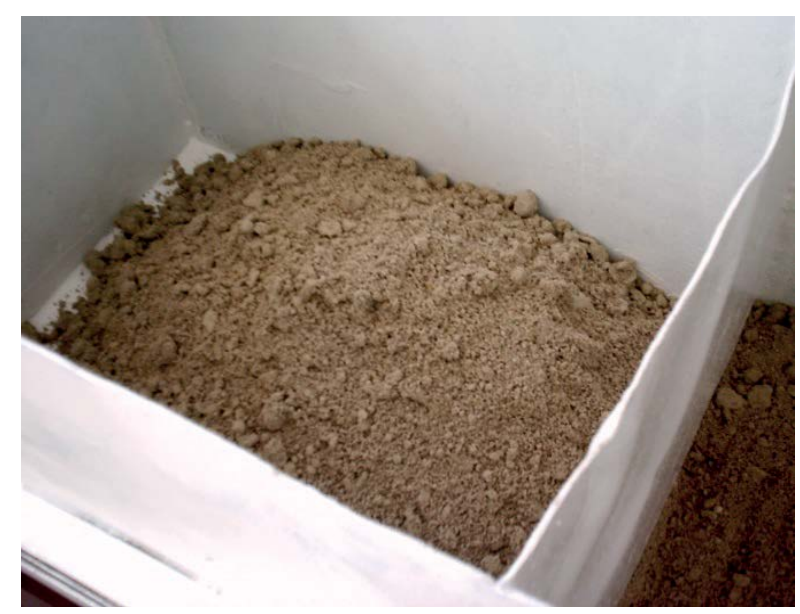

Figure 2: Placement of soil into tank

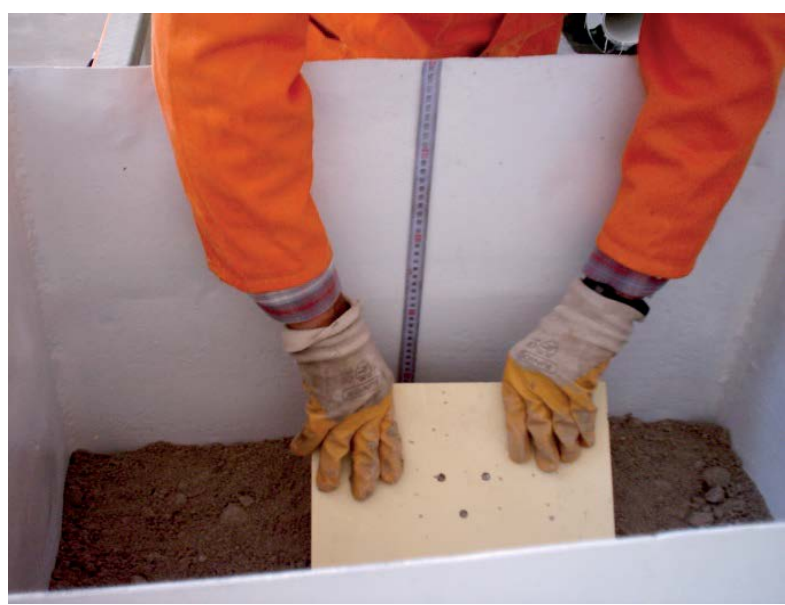

Figure 3: Compaction procedure. respectively. Heavy metals, such as $\mathrm{Cu}$ and $\mathrm{Cr}$, were added over the compacted layers at the end of a 28 day curing period (Figure 5).

Distilled water was also added to the other sections for comparisons. Room temperature was kept at $15-18{ }^{\circ} \mathrm{C}$ over the 16 weeks of 
Citation: Tuncan A, Onur MI, Akpinar K, Tuncan M (2016) Use of Sepiolite and Zeolite Mixtures as a Landfill Liner. Int J Waste Resour 6: 197. doi: 10.4172/22525211.1000197

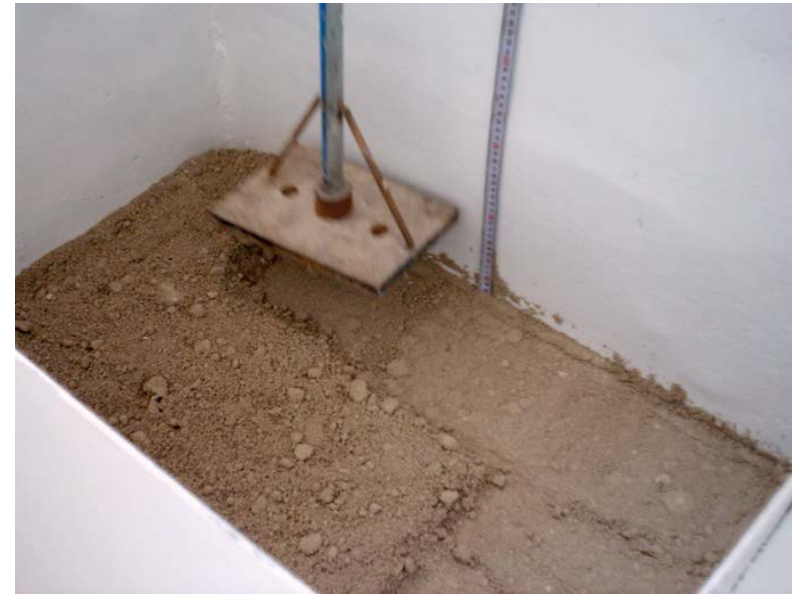

Figure 4: Compaction procedure.

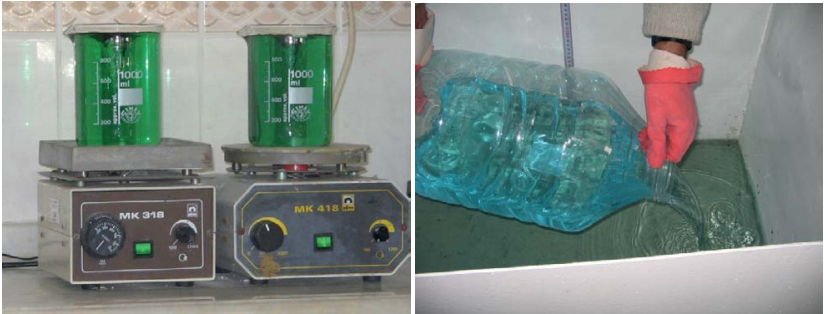

Figure 5: Preparation procedure and addition of $\mathrm{Cu}$ and $\mathrm{Cr}$ solutions into the sections.

observations. The miniature landfill was covered in nylon to prevent evaporation from the liquids as shown in Figures 6 and 7.

Leakage samples were collected from the bottom of the tank (Figure 8) and kept in a refrigerator. The liquids in the landfill tank were discharged at the end of the 16 week period. The geotechnical and physico-chemical properties of the impermeable layers in the sections were determined. Scanning electron micrograph pictures were also taken to observe the change in the micro-structural properties of the mixtures.

\section{Results and Discussion}

\section{Atterberg consistency limits, unconfined compressive} strength and permeability

Atterberg consistency limits, unconfined compressive test (UCS) results, permeability and the coefficient of compression values of the mixtures are given in Table 2. It can be seen that the addition of $\mathrm{Cr}$ and $\mathrm{Cu}$ decreases plasticity and strength values, but increases the permeability and coefficient of the compression values of the $S / Z=0.3$ mixtures after the 16 week curing period. The PI values are less than $50 \%$, so the required value for the samples used as hazardous landfill should be less than $50 \%$ [8]. The permeability values are also less than $1 \times 10^{-7} \mathrm{~cm} / \mathrm{sec}$, so the permeability results are within limits.

\section{Electrical conductivity, ph and cation exchange capacity}

The accumulation and migration of salt were measured using a conductivity meter (Omega CDB-70). Approximately two hundred and

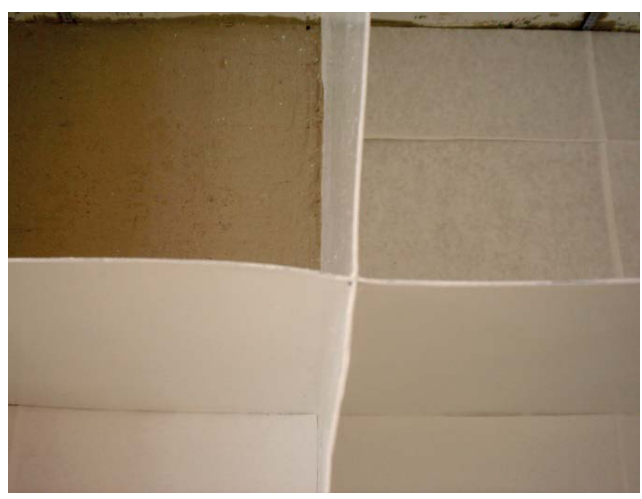

Figure 6: Curing procedure.

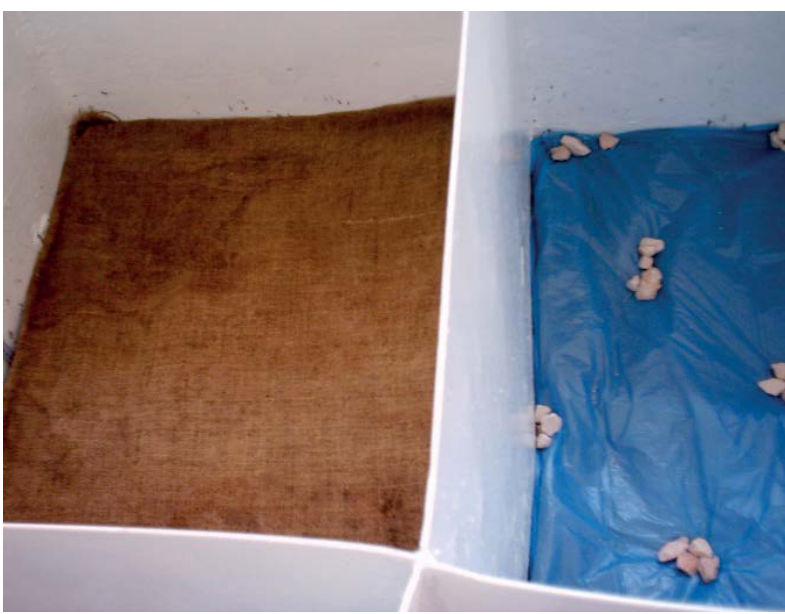

Figure 7: Curing procedure.

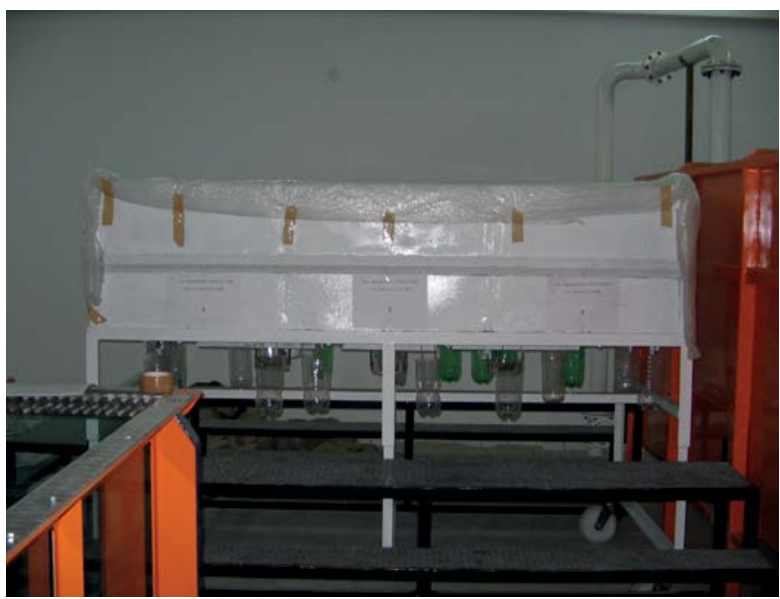

Figure 8: Leakage collection procedure.

fifty grams of air dried $\left(20^{\circ} \mathrm{C}\right)$ specimen were sieved through a No. 16 sieve, and homogeneously mixed with distilled water to make a paste. This was then left for 24 hours to determine the electrical conductivity (EC) of the mixtures $[12,13]$. The electrical conductivity values are less 
Citation: Tuncan A, Onur MI, Akpinar K, Tuncan M (2016) Use of Sepiolite and Zeolite Mixtures as a Landfill Liner. Int J Waste Resour 6: 197. doi: 10.4172/22525211.1000197

\begin{tabular}{|c|c|c|c|c|c|c|}
\hline Materials & $\begin{array}{l}\text { LL } \\
(\%)\end{array}$ & $\begin{array}{l}\text { PL } \\
(\%)\end{array}$ & $\begin{array}{l}\text { PI } \\
(\%)\end{array}$ & $\begin{array}{l}\text { UCS } \\
(\mathrm{kPa})\end{array}$ & $\begin{array}{c}k \\
(\mathrm{~cm} / \mathrm{sec}) \times 10^{-8}\end{array}$ & Cc \\
\hline $\begin{array}{c}S / Z=0.3 \\
\text { (Compacted) }\end{array}$ & 68 & 45 & 23 & 292 & 1.17 & 0.240 \\
\hline Cr Solution & 73 & 65 & 8 & 55 & ---- & 0.278 \\
\hline Cu Solution & 75 & 59 & 16 & 105 & 3.50 & 0.248 \\
\hline Distilled Water & 76 & 63 & 13 & 71 & ---- & ---- \\
\hline
\end{tabular}

than $4 \mathrm{mS} / \mathrm{cm}$, so this value is within limits. General views of the $\mathrm{Cu}$ and $\mathrm{Cr}$ contaminated and the distilled water sections of the tank after the test are given in Figures 9-11, respectively.

The $\mathrm{pH}$ of the specimens was measured using a $\mathrm{pH}$ meter (Cole Parmer $39000-50)$. A twenty gram specimen of air dried $\left(20^{\circ} \mathrm{C}\right)$ was sieved through a No. 40 sieve, homogeneously mixed with $50 \mathrm{ml}$ of distilled water and left for one hour to determine the $\mathrm{pH}$ of the mixtures according to the EPA Method 9045 (1986). The $\mathrm{pH}$ values are all between 8,0 and 8,5 . The soil $\mathrm{pH}$ should be between 6 and 8 to minimize any immobilization of heavy metals. Cation Exchange capacity (CEC) is an important parameter for the attenuation of leachate through a clay landfill liner. If the CEC of a clay liner is high, more contaminants are removed from the leachate. The CEC was determined by the sodium saturation method [14]. The electrical conductivity, $\mathrm{p}^{\mathrm{H}}$ and cation exchange capacity values of the specimens are given in Table 3 . The cation exchange capacity values found in the experiments are enough to hold heavy metals in soil.

\section{Total heavy metals}

The $\mathrm{Cu}$ amount of $10 \mathrm{~cm}$ thick $\mathrm{S} / \mathrm{Z}=0,3$ specimen is around zero, which means that there is no leaching through the specimen. There is also no leaching through the $10 \mathrm{~cm}$ thick specimen with distilled water above it. There is leaching through the $5 \mathrm{~cm}$ thick specimen which have $\mathrm{Cr}$ and $\mathrm{Cu}$ above it. The $\mathrm{Cr}$ and $\mathrm{Cu}$ amounts in the leachate samples are $0,2 \mathrm{mg} / \mathrm{lt}$ and $0,227 \mathrm{mg} / \mathrm{lt}$, respectively. These heavy metals are below limits $(\mathrm{Cu}=0,005-9,9 \mathrm{mg} / \mathrm{lt}$ and $\mathrm{Cr}=0,2-18 \mathrm{mg} / \mathrm{lt})$ [15].

\section{Scanning electron microscopy}

Undisturbed specimens were prepared for a scanning electron microscopy (SEM) analysis. The specimens were examined for microstructure (fabric) by SEM and for chemical composition by the energy dispersive $\mathrm{x}$-ray (EDX) technique, using an LEO 440 model scanning electron microscope. The specimens were dried in an oven at $105^{\circ} \mathrm{C}$ and were held on an aluminum sample holder with adhesive tape. Later, they were coated with gold to minimize any charge build up and were examined under the SEM. The specimens were then scanned for chemical composition using EDX.

The scanning electron microscope is an ideal tool to observe features of the fabric of soil. Soil microstructure is a function of the fabric and the physico-chemistry of the soil waste additive system. Microstructural units are not only composed of single particles, but also compound particles held together by physico-chemical forces. The compound particles are domains, aggregates, agglomerates, flocculates and organic compounds. Physico-chemical forces are responsible for aggregating clay particles and binding them together.

Scanning electron micrographs of the $S / Z=0,3$ mixture with distilled water are shown in Figures 12 and 13. It can be seen from the figures that the zeolite particles are of cubic form. The scanning electron micrographs of the $\mathrm{S} / \mathrm{Z}=0,3$ with $\mathrm{Cu}$ and $\mathrm{Cr}$ solution samples are shown in Figures 14-17, respectively. Flocculated and aglomareted

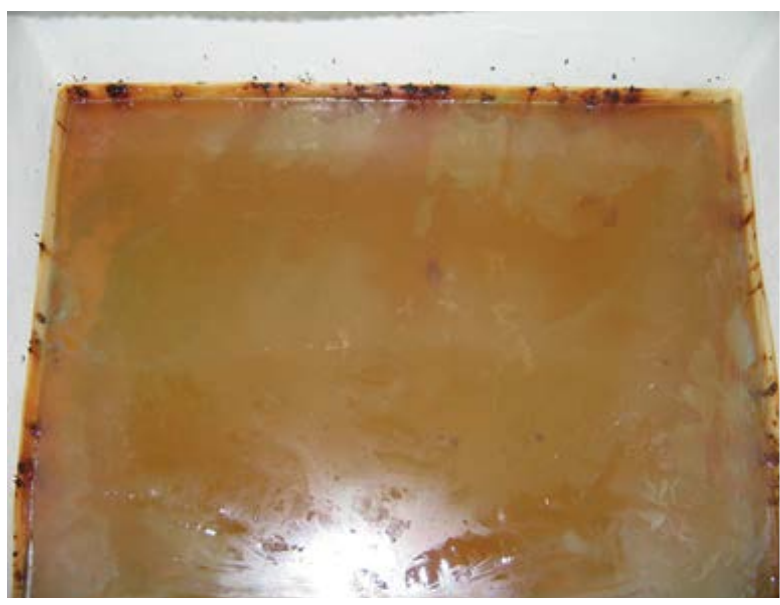

Figure 9: Cu contaminated mixture.

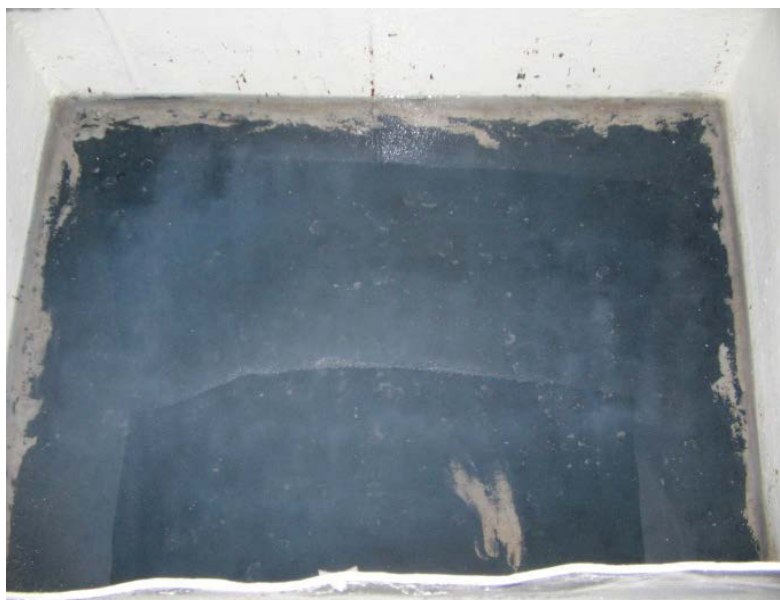

Figure 10: Cr contaminated mixture.

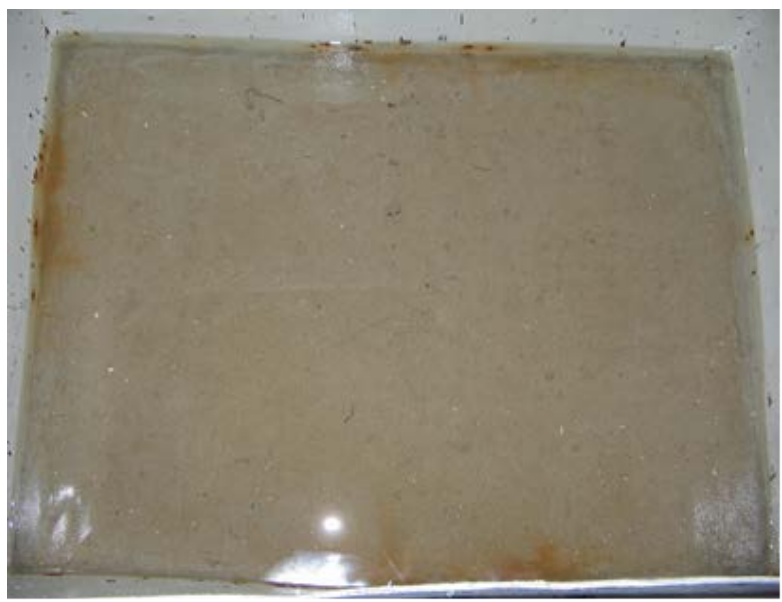

Figure11: Distilled water added mixture. 
Citation: Tuncan A, Onur MI, Akpinar K, Tuncan M (2016) Use of Sepiolite and Zeolite Mixtures as a Landfill Liner. Int J Waste Resour 6: 197. doi: 10.4172/22525211.1000197

structures can be observed from these figures. When the zeolite is mixed with water, agglomerated structures may form. After adding sepiolite to the zeolite, the agglomerated structures are cemented and bonded. The addition of $\mathrm{Cu}$ and $\mathrm{Cr}$ breaks the bonds between the particles and the sample therefore becomes less aggregated and flocculated.

\section{Conclusion}

This study shows that zeolite-sepiolite mixtures can be effectively used in bottom lining systems for hazardous, industrial and municipal

\begin{tabular}{|l|l|l|l|}
\hline Materials & pH & E.C.(mS/cm) & CEC $(\mathbf{m g} / \mathbf{l t})$ \\
\hline Cr Solution & 8,40 & 0,55 & 58,83 \\
\hline Cu Solution & 8,03 & 0,60 & 57,74 \\
\hline Distilled Water & 8,10 & 0,40 & 56,52 \\
\hline
\end{tabular}

Table 3: Results of electrical conductivity (e.c.), ph, cation exchange capacity.
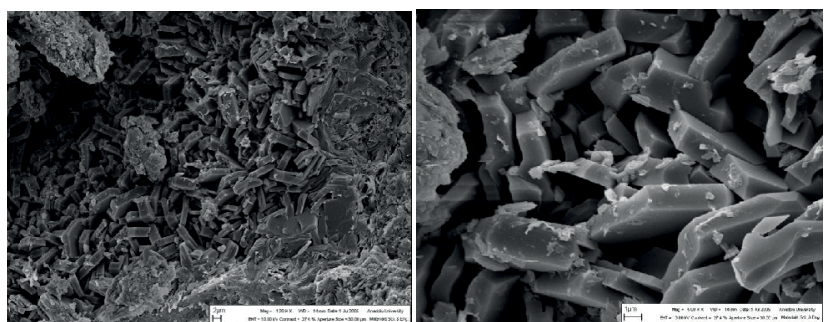

Figure 12: $S E M$ micrographs of $S / Z=0.3(1000 X-5000 X)$ [15].

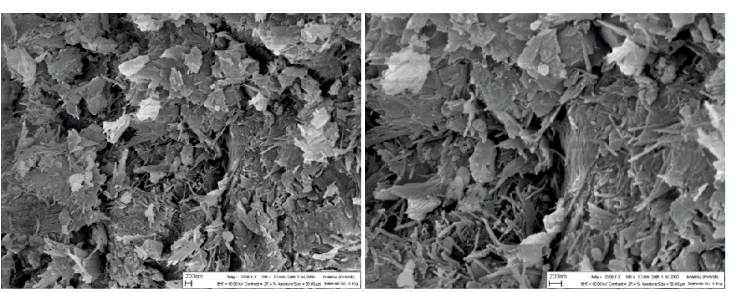

Figure13: SEM micrographs of $S / Z=0.3(10000 X-20000 X)$ [15].
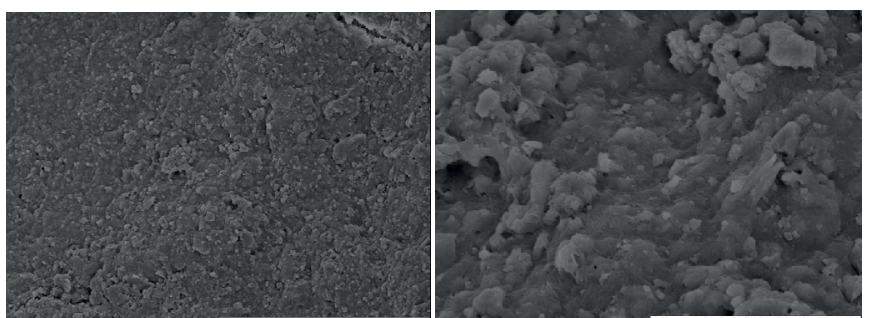

Figure 14: SEM micrographs of $S / Z=0.3$ with Cu solution (1000X - 5000X) [15]
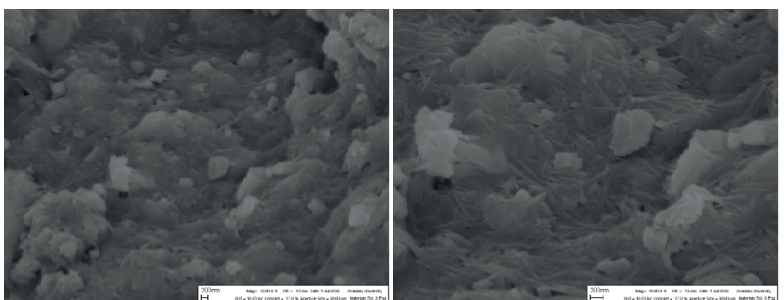

Figure 15: $S E M$ micrographs of $S / Z=0.3$ with $\mathrm{Cu}$ solution $(10000 \mathrm{X}$ 20000X) [15]

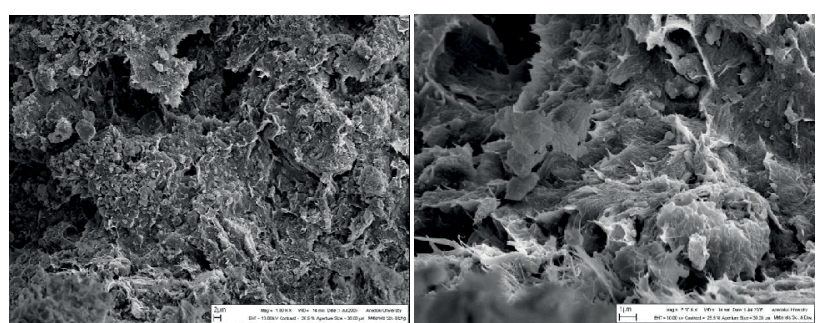

Figure 16: SEM micrographs of $S / Z=0.3$ with $\mathrm{Cr}$ solution (1000X - 5000X) [15].
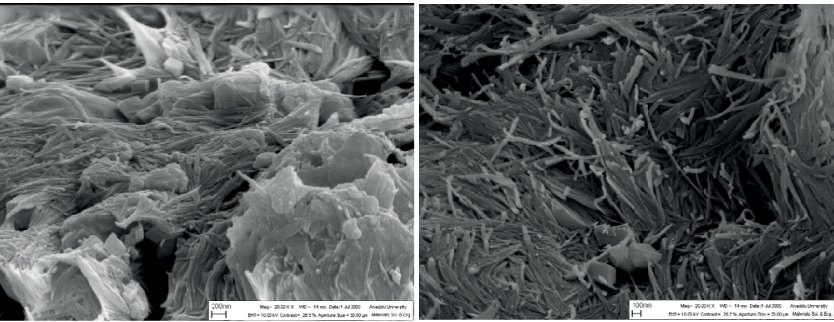

Figure 17: SEM micrographs of $S / Z=0.3$ with $C r$ solution (20000X - 25000X) [15]

waste. The sepiolite-zeolite mixtures proposed in this study, not only exhibit low permeability, but would also act as an efficient chemical filter. The cation exchange capacity of zeolite is measured at very high levels compared to sepiolite. Therefore, heavy metals, such as $\mathrm{Cu}$ and $\mathrm{Cr}$, can be held by zeolite [16]. Sepiolite-zeolite mixtures having a ratio of S/Z:0.3 can also be used as a hazardous landfill liner. On the other hand, this study is performed for specific soil properties and heavy metals, so additional research is recommended for other conditions.

\section{References}

1. Güney Y, Cetin B, Aydilek AH, Tanyu BF, Koparal S (2014) Utilization of sepiolite materials as a bottom liner material in solid waste. Waste Manag 34: 112-124.

2. Sun Y, Zhao D, Xu Y, Wang L, Liang X, et al. (2014) Effects of sepiolite on stabilization remediation of heavy metal-contaminated soil and its ecological evaluation, Front. Environ Sci Eng 10: 85-92.

3. Benson $\mathrm{CH}$, Zhai $\mathrm{H}$, Wang X (1994) Estimating hydraulic conductivity of compacted clay liners. Journal of Geotechnical Engineering 120: 366-387.

4. Simon F, Muller W (2004) Standard and alternative landfill capping design in Germany. Environmental Science \& Policy 7: 277-290.

5. Jain P, Kim H, Townsend $\mathrm{T}$ (2005) Heavy metal content in soil reclaimed from a municipal solid waste landfill. Waste Management 25: 25-35.

6. Tuncan A, Tuncan M, Koyuncu H, Güney Y (2002) Use of natural zeolites as a landfill liner. Waste Manag Res 21: 54-61.

7. Özdemir AHV (2004) Determining of using sepiolite in sanitary landfill liners Anadolu University Graduate School of Sciences, Master of Science Thesis.

8. Daniel DE (1993) Early days of environmental geotechnology. Chapman \& Hall Public.

9. Grim RE (1968) Clay mineralogy. McGraw Hill.

10. Bish DL, Guthrie GD (1993) Mineralogy of clay and zeolite dusts Chapter 4 in health effects of mineral dusts. Reviews in Mineralogy 28: 139-184.

11. Kabakcı EM (2004) Determining geotechnical properties of sepiolite and zeolite mixtures used proposed in the sanitary landfill liner. Anadolu University Graduate School of Sciences, Master of Science Thesis.

12. Wilcox JC (1946) Determination of electrical conductivity of soil solution Science Agronomy 32: 107-117.

13. Karakouzian M, Pitchford A, Leonard M, Johnson B (1996) Measurement of soluble salt content of soils from arid and semi-arid regions. Geotechnical 
Citation: Tuncan A, Onur MI, Akpinar K, Tuncan M (2016) Use of Sepiolite and Zeolite Mixtures as a Landfill Liner. Int J Waste Resour 6: 197. doi: 10.4172/22525211.1000197

Page 6 of 6

Testing Journal 19: 73-80

14. Chopman HD (1965) Cation exchange capacity in methods of soil analysis Series Agronomy. A Inst Agronomy 9: 891-901.

15. Akpinar K (2005) The use of sepiolite and zeolite mixtures in the design of the hazardous waste landfill areas. Anadolu University Graduate School of
Sciences, Master of Science Thesis.

16. Tuncan A, Akpinar K, Tuncan M, Onur MI (2008) The use of sepiolite and zeolite mixtures to design the hazardous landfill area.s 7th International Conference on Role of Engineering Towards A Better Environment (Global Environmental Changes: Challenges and Opportunities) (RETBE'08). 